\title{
Value of the architecture in the nodal place of the city. Palace in Radzyń Podlaski as an integrating monument
}

\author{
Jan Wrana \\ Independent Architectural Design Studio, Faculty of Civil Engineering and Architecture, \\ Lublin University of Technology,
}

\begin{abstract}
This article discusses the value and integration role of a node-based architecture $^{1}$ - the „node of the city" ${ }^{2}$. These buildings can be divided into two types: new buildings (constructed in the last decades) and historic ones - existing in historical nodes for years. These are, for the most part, public utility facilities, often hosting cultural institutions - philharmonic, opera, art institute. In addition to the basic function of the program, they play an integrating role - both spatially and socially. Many of them are dominant in their surroundings, and are often the showpieces of their cities.

The article discusses both types mentioned above: contemporary and historical. Selected examples of particularly interesting new cultural facilities located in the nodes of Oslo, Hamburg and Amsterdam, whose influence on the city was positive and clear. In the field of historic buildings special attention was paid to the Potocki Palace - the most important node of the town Radzyń Podlaski, which by way of revitalization regains its integrating function.

Keywords: architecture, integration, nodal places, Radzyń Podlaski, synergy.
\end{abstract}

\section{Introduction}

According to UN's demographic data, since 2008, for the first time in the history towns and cities majority of people live in urban areas. People, especially the young ones, participate in a mass migration to urban areas and this trend is not weakening. The urban organism has become a subject of research and in the second decade of the $21^{\text {st }}$ century, the awareness of the necessity to create a cohesive and sustainable urban structure is gradually growing. Jan Gehl's slogan "Cities for people" gains a very up-to-date character and is widely promoted and more and more keenly implemented. An increasing number of programmes enlivening the so far neglected districts is observed. The necessity to coalesce the urban structure and the

1 K. Lynch. The image of the City,1960 (Polish translation by Tomasz Jeleński, editing of the Polish edition by Wojciech Kosiński), Wydawnictwo Archivolta Publishing House, Kraków, 2011 Chapter III The Image of the City and its Elements, p. 53. Nodes, p. 84.: Nodes are points, the strategic spots in a city into which an observer can enter; usually junctions or crossings, or concentrations. Despite the fact that, conceptually, they are small points in the image of the city, they can actually be large squares, or slightly stretched linear forms, or even entire districts, when the city is analysed in a sufficiently broad scale. When one images the environment at a national or international scale, even a whole city may become a node.

2 Z. K. Zuziak, On the synergy of urban plan, (Conference Publication "Synergia w architekturze" [Synergy in Architecture] Lublin 2016, scientific editor: Jan Wrana), "Budownictwo i Architektura" Publishing House, vol. 16 (1)2017 p.188: (...) The term of "nodes of urbanity" can be defined as referring to places which, due to accessibility, spatial management values, and other highly praised values, are of key importance to contemporary forms of urban life. Nodes of urbanity are also places which-according to economic geography - correspond to peaks of property value at diagrams illustrating the profiles of metropolitan space value. 
role of architecture in this process is also emphasised. Measures are undertaken to counteract further dispersion of cities; limiting the spatial chaos and erecting facilities respecting the context and present neighbourhood are proposed.

For several years now, and initially only as part of scientific discussions, the question of architecture value in a city's key node has been reoccurring. "Urban nodes" are important points on the city map, where the local tracts are intersecting in the most representative important sites of the town. They should become integrating points on multiple levels: spatial (e.g. districts, parts of the street, or composition axes) as well as the social one (generations, professions, religions, cultures). These facilities may be divided into two groups: new facilities (erected over a period of a few, perhaps a dozen or so years) and the existing ones (often of historical value)

\section{Selected facilities in key nodes}

Out of a group of interesting examples of new architecture in key nodes, attention should be drawn to the following examples from Oslo, Amsterdam and Hamburg. The Opera House in Oslo, Elbphilharmonie and Zentraler Omnibusbahnhof in Hamburg and Eye Film Institute Netherlands in Amsterdam have become the symbols and landmarks of their cities. All of these facilities are characterised with high quality of architecture, carefully selected and designed function as well as situation in an important and significant place. Thanks to the combination of the integrating function and the key node, we can observe in their case the synergy phenomenon - an added value thanks to which these facilities have a much stronger influence compared to their being located in a different place. In the case of the Opera House, Philharmonics and Eye Film Institute, we additionally have to do with the revitalisation of degraded river banks, where the aforesaid facilities played an important role. Their interesting function, attractive for the inhabitants and tourists converted directly into an increased traffic in the neighbourhood and what follows - its enlivening. The railway station on the other hand has become a modern gatehouse of the city welcoming tourists arriving in Hamburg.

\subsection{Oslo Opera House}

Since the 1980s, Oslo has been carrying out the port revitalisation project entitled: "Oslo Sea Facade", or the Fjord City. The subsequent districts such as for example Aker Brygge (since 1980), Bjørvik (since 2000), Tjuvholmen (since 2005) have undergone the image as well as functional transformations. As a result of these activities, the seaport space has changed its function fundamentally: from a warehouse and transportation basis into a representative one. It is now a trendy and much visited district where important facilities are situated.

The crowning point of these changes is the National Opera House handed over for use in 2007. The building designed by Snøhetta Architectural Studio is a futuristic yet elegant facility made from glass and white marble - erected in the place of a former sea port market place, which was also a centre of the medieval town. It immediately became a dominating element of the embankment and the symbol of the entire city. It is situated on the edge of the Bjørvik district, not far from the stock exchange and the main railway station. 

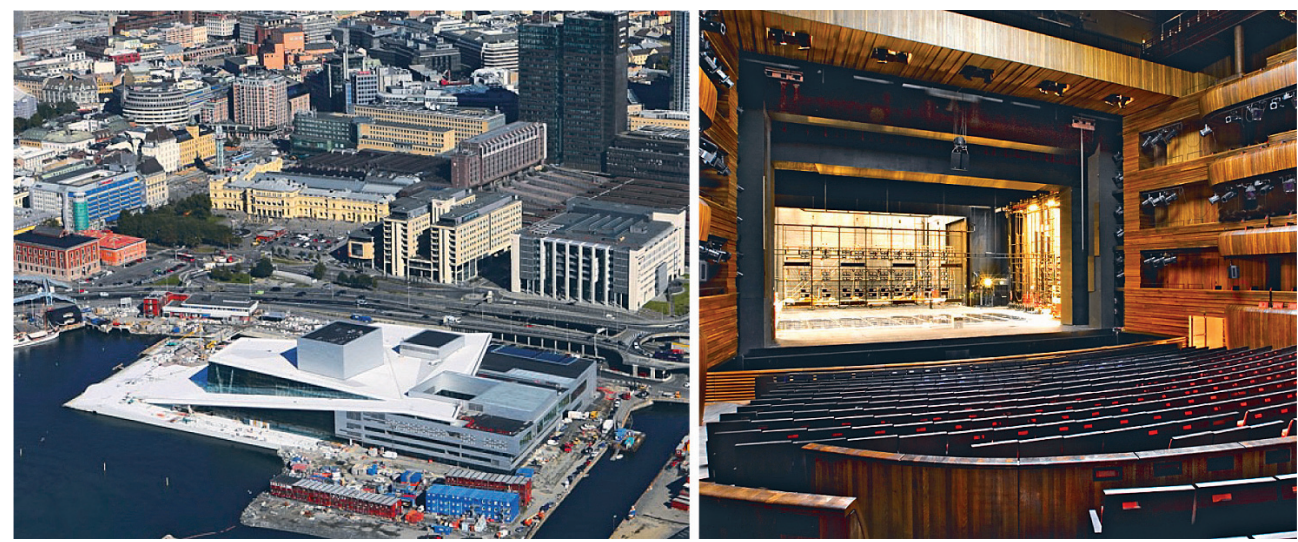

Fig. 1. "Oslo Sea Facade", i.e. the Fjord City with the National Opera and Ballet House

Fig. 2. The National Opera and Ballet House - the interior

\subsection{Amsterdam - the Eye Film Institute Netherlands}

This extremely characteristic, bold and at the same time very elegant building of the Eye Film Institute is a key node of the revitalised industrial area of Amsterdam. Due to its shape, it is also referred to as the "shark" emerging from the bay. The expressive and dynamic edifice, with strong lines, was mitigated with the facade colour. The white coincides with the blue of the water and the sky thus producing a savoury composition. The facility completed in 2012 was designed by the Austrian studio Delugan Meissl (Elke Delugan-Meissl and Roman Delugan).

The Eye Institute combines the function of a museum and of an archive. Its rich collection includes 37000 films, 60000 posters, 700000 photos and 20000 books. Situated in the building is also a café visited not only by the visitors to the Museum but also by the "public at large".

The light, horizontally situated building of the Eye is manifestly distinct from the neighbouring Overhoeks tower - a strong, dark, vertical form. It remains with it in a peculiar
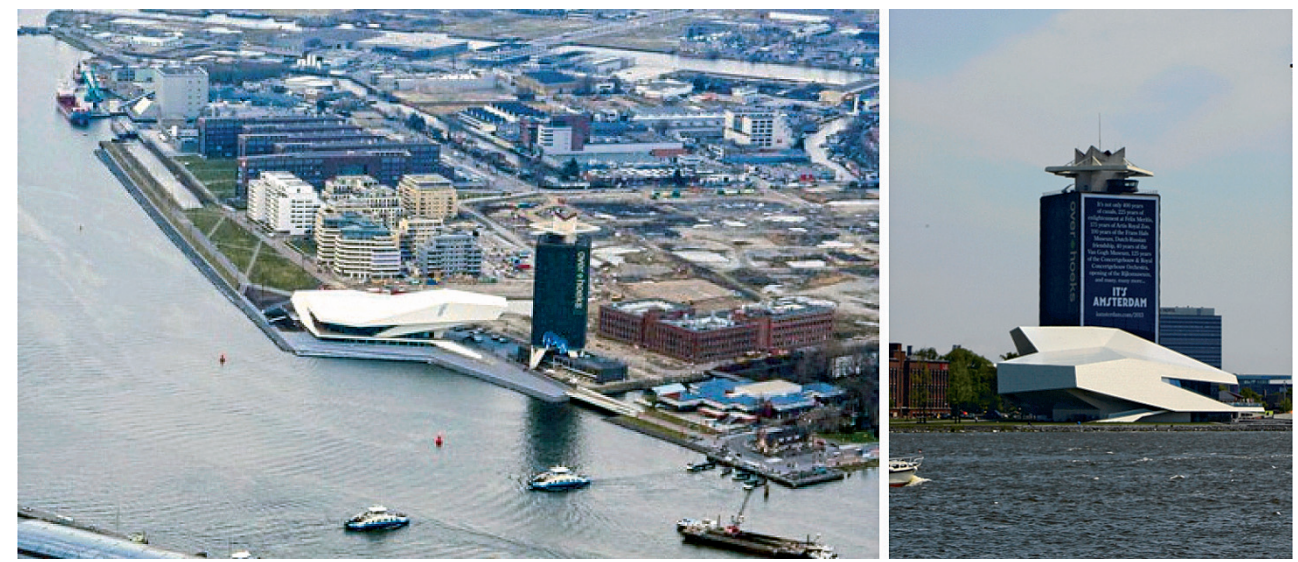

Fig. 3, 4. The Eye Film Institute Netherlands, author's photos, 2013 
formal symbiosis and at the same time it moulds the post-industrial embankment. They are clear, dominating elements of Amsterdam Noord and at the same time a bridgehead prepared for new investment projects in this northern part of the city. It is less representative and appreciated in comparison with the southern extremities of the city with for example the Old Town and the white-collar district of Zuidas; however, this situation seems to change year to year.

\subsection{Hamburg - Elbphilharamonie}

A newly erected philharmonic, completed in 2017, is an unquestionable symbol of HafenCity. A bold shape of the building is the concept of a Swiss duet Herzog \& de Meuron. The building is a transformation of one of the two largest warehouses, i.e. the former Speicherstadt, designed in the 1960s by Werner Kallmorgen - Kaispeicher A. where cocoa and root spices were warehoused.
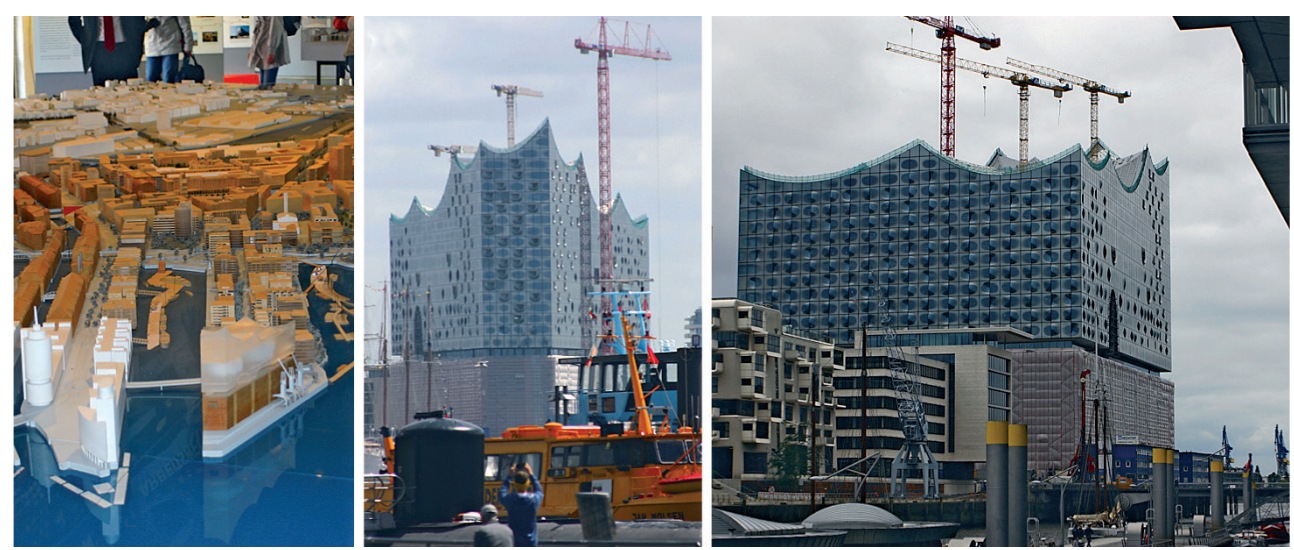

Fig. 5, 6, 7. Hamburg - Elbphilharamonie. Author's photos, 2014

The brick base of the building is an allusion to former architecture of Speicherstadt, while the light, glazed top reminds of a sail - as a result the entire building may be associated with the ship coming into the port. Inside, on the 26 floors, in addition to the rooms used by the Philharmonics (there are three concert halls, backup facilities, orchestra rooms, etc.); there are also residential apartments and a five-star hotel with nearly 250 rooms, conference rooms, a car park and a night club.

The facility is situated at the extreme end of the HafenCity peninsula and is a clearly dominating point over the neighbourhood - due to its size (110 m high, $200 \mathrm{~m}$ long - it is the tallest building in the city) as well as its strategic location, well before the official launch, it had become a modern showcase of the city, its contemporary symbol - in a similar fashion as the Opera House in Sydney, or in Oslo. It is a new node whose construction is strictly linked with the philharmonics function - in this case, this facility had influence on the establishment of the node.

\subsection{Hamburg - Zentraler Omnibusbahnhof}

The intriguing roof of the main bus station in Hamburg is a work of ASW Archiekten and Silcher-WernerRedante. The characteristic "sail" (also referred to as the "boomerang") soon became the way point much helpful in finding the station. 
The glazed roof, resting on a single, tall colonnade towers over the service buildings and the entire station. The roofs over the bus spaces, supported by brackets on one side and only held on the one side, offer protection to the underground tunnel situated on the other side of the building without disrupting its function. The structure of the roof consists of a steel rib (curved vertically beam), bracket beams and glazed panels.
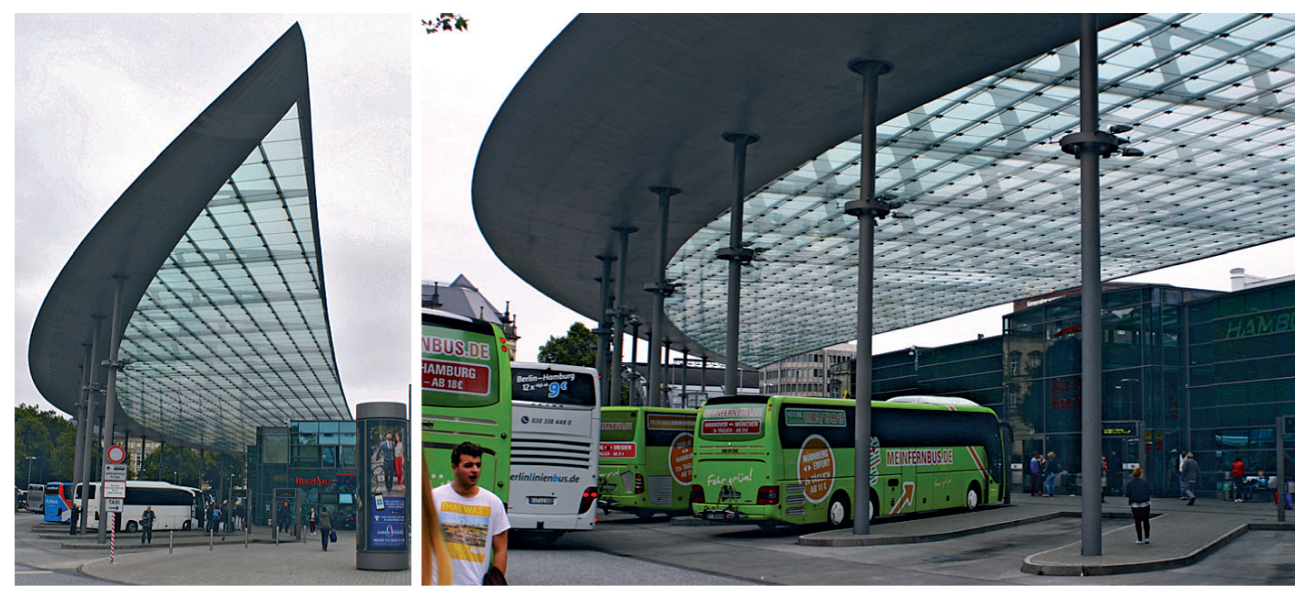

Fig. 8, 9. Central Bus Station in Hamburg - Zentraler Omnibusbahnhof. Photos by the author 2014.

The whole structure is extremely light, elegant, recognisable and dynamic. The imposing roofing soon became accepted by the inhabitants and is also an attractive city "gatehouse" welcoming visitors to Hamburg arriving by bus. It is yet another urban terminal of the city - this time, however, more classical as it is linked with a transportation function: a starting point, destination and transfer point.

\section{A historic value facility - restoring the integrating function - Radzyń Podlaski}

Another trend, in addition to building new facilities in the key nodes integrating sites spatially and socially is restoration of the integrating function in the existing historic nodes. We often encounter a situation where valuable, or even basic urban nodes lost their importance due to functional, urban planning, or disadvantageous historical events.

This is precisely the case of Potocki Palace in Radzyń Podlaski - the introduction of the judicial function into the facility resulted in a situation where it no longer integrated the inhabitants. The precious facility was adapted to satisfy ongoing needs and modernised as offices. Pushed to the other plan is the question of inheritance and historic value - the Palace was difficult to access by tourists and ceased to be the landmark of the city. Moving the judicial function into a new building erected 2015, opened a new path for the Palace revitalisation - transforming it into a cultural facility integrating the local community, tourists, the entire city and surrounding areas. The upgrading of the Palace and its adaptation to a new function will be carried out in accordance with the conserver's guidelines so as not to diminish its role as the relic of the past; this role will be reminded by a modern museum to be organised in the facility. As a tourist attraction it may also contribute to the return of its former inhabitants 
(who left it in pursuit of job opportunities in bigger cities) by creating work opportunities and enlivening the tourist market (accommodation, catering, souvenirs).

\section{Overview of the history of the palace and the town}

The history of today's Radzyń dates back to the 15 th century and its beginnings are linked with the medieval settlements of Białka, Białka Niżna and Kozirynek. The village development was fostered by its convenient situation in the vicinity the intersecting, important commercial routes - from Krakow to Vilnius and from the Mazovia region to Rus. The proper town of Radzyń was granted town privileges by the charter of King Casimir Jagiellon back in 1468 and was situated ca. $1 \mathrm{~km}$ north of Kozirynek, in the place of a parish founded 22 years earlier.

Since the very beginning of the city, there was a castle in there which at the same time was a defensive structure and the seat of the city owner.

In the $15^{\text {th }}$ and $16^{\text {th }}$ centuries, the palace was a medieval stronghold (fortalice). In the mid$16^{\text {th }}$ century, it was reconstructed in the Renaissance style - as a result of the works a palazzo in fortezza type of building was erected. In 1685, the upgrading works recommenced according to the design by Augustyn Wincenty Locci, the outcome of which was a Baroque style representative and defensive facility with an extensive garden. In mid-18 ${ }^{\text {th }}$ century another reconstruction took place - this time in the Rococo style. The works were managed by Jakub Fontana, and this shape of the building has been preserved until the present moment.

Worth mentioning is also the Holy Trinity parish church, erected in the period 1612-1641 upon funding by the Mniszech family - the then owners of the Radzyń land. It is regarded as one of the leading architectural facilities of the so-called Lublin Renaissance. ${ }^{3}$

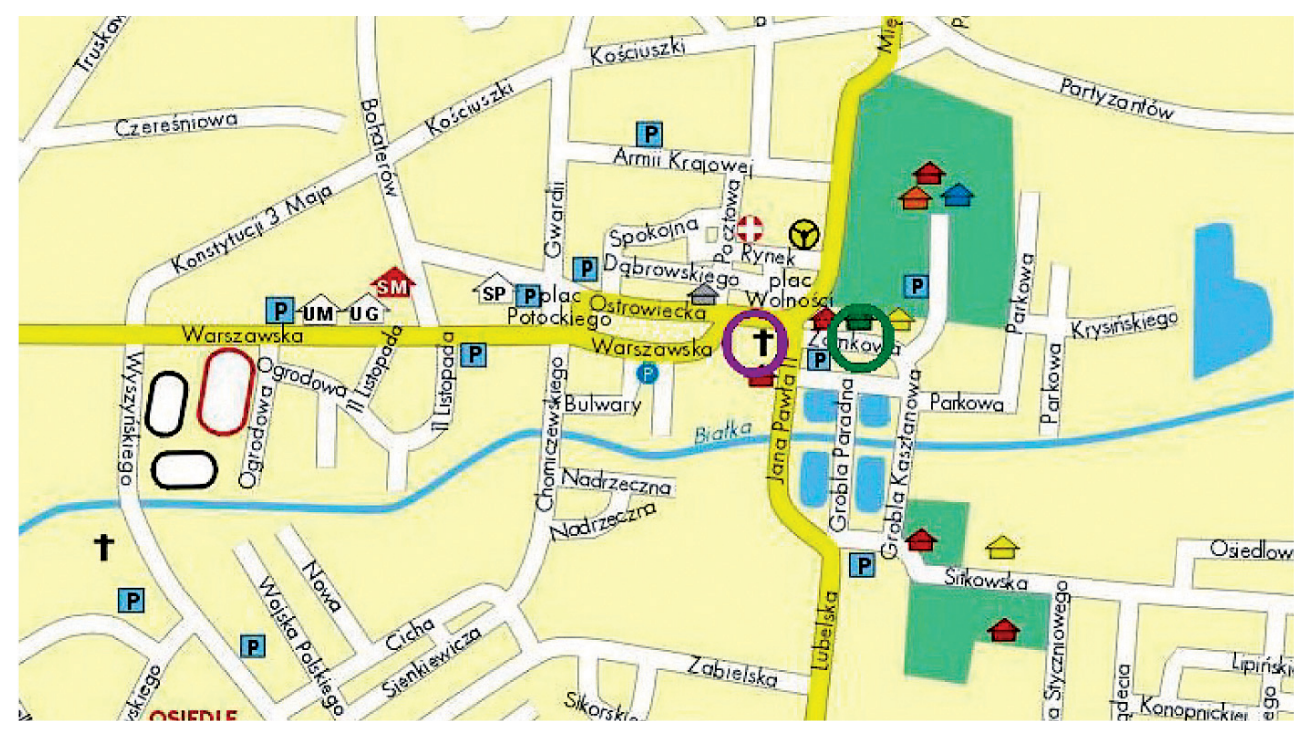

Fig. 10. Radzyń Podlaski - the location of the palace, the park (green circle, from the right) and the parish church (purple circle, from the left).

\footnotetext{
3 The main altarpiece is decorated with the image of the „Holy Trinity” (1892) by a famous religious painter Józef Buchbinder. Inside, attention is drawn by a single-storey tomb of Mikołaj and Zofia Mniszech; it was probably co-produced by Santi Gucci, the author of among other things the tomb of king Sigismund August at the Wawel Cathedral.
} 
Throughout centuries, Radzyń Palace was the most prominent and the largest building in town. The town's prestige grew thanks to it and its name became popular also outside Poland. It was the heart of the town whose primary function was to offer a shelter to later become the town's landmark, a place of furious discussions and sumptuous parties. Many famous people visited the site, unfortunately the $19^{\text {th }}$ century brought the decline of its importance with the $20^{\text {th }}$ century finally putting an end to the time of its glory.

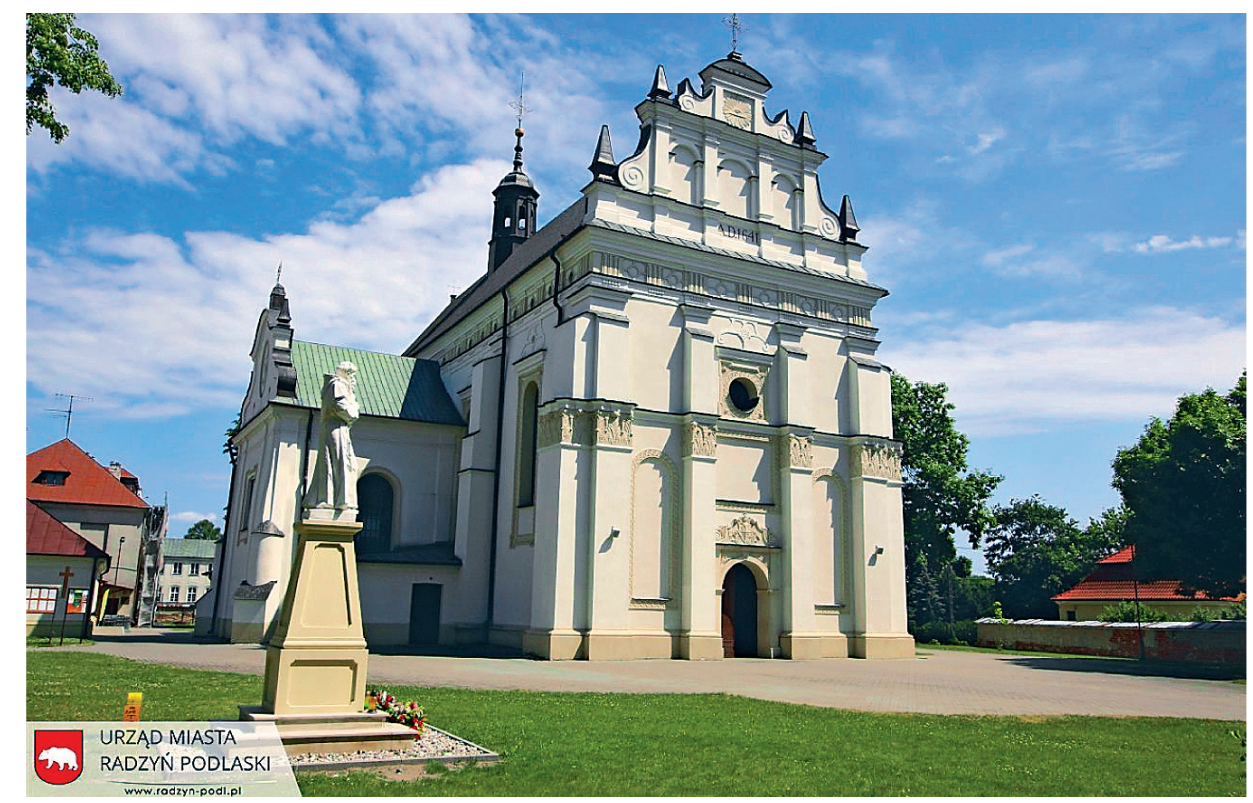

Fig. 11. Holy Trinity parish church. Source: radzyn-podl.pl [entry: 10.10.2017]

In 1920, the palace became the property of the State Treasury. In the inter-war period it was the headquarters of the state authorities and during the World War II it was the headquarters of the German administration. In July 1944, during the retreat of the German army, the palace was set on fire which caused enormous damage, especially inside the building. After the War, the building was reconstructed and used by the regional authorities. Over the years, the historical interior was the host to a court and cultural institutions such as a musical school, or a library. The rooms were adapted to these functions by introducing for example additional partition walls (secondary division of the interior), which transformed the once representative and spacious rooms into small offices.

The Rococo pearl began to be associated mainly with files and court rulings. The inhabitants avoided this place and tourists did not have any motivation to visit it either. The Palace was kept in acceptable technical condition (the necessary repairs were made and the building was protected against devastation), however its potential and possibilities withered.

\section{Revitalisation of the palace and revitalisation programme City of Radzyń Podlaski}

In connection with the transfer of the court into new headquarters in 2015, the palace was acquired by the municipality. A discussion started at the same time concerning introduction 
of a new function into it. Bearing in mind the importance and role of the palace, the municipal authorities decided to establish a cooperation with Lublin University of Technology. In June, 2017 an agreement was signed between the investor, i.e. the Mayor of the City of Radzyń and the contractor, i.e. Politechnika Lubelska, whose aim was: "The Revitalisation of the Palace and Park of the Potocki Family in Radzyń Podlaski".

The appointed project team was supervised by the Main Designer, architect Jan Wrana, ${ }^{4}$ The programme of the modernised facility determined in agreement with the ordering authority (i.e. the Municipality) included Centrum Kultury Polski Wschodniej (Centre of the Eastern Poland Culture). It is a modern, multidisciplinary centre bringing together several functions: a museum with the preserved historical interior, historical photography and classical films lab, old-age people's club, cafe, youth organisations headquarters and the Polish Scouting Association [ZHP]. It is a place of meetings and activity but also a place of cherishing the memory of the multicultural nature of this region of Poland.

The purpose of the revitalisation was to restore the Palace to the inhabitants of Radzyn and recovering its lost renown. The so valuable facility deserves being revived and brought back to a vibrant state. The palace has an enormous potential whish should be properly utilised - its representative architecture, extensive park and garden grounds, and convenient location should serve the residents of Radzyń and tourists visiting the site.

Radzyń Palace is an "urban node" - it is the most important place on the city map (spatially and immaterially), testifying to its identity, a relic of the former glory and a landmark at the same time. The Palace was a driving force of the city's development with the urban tissue growing around it.

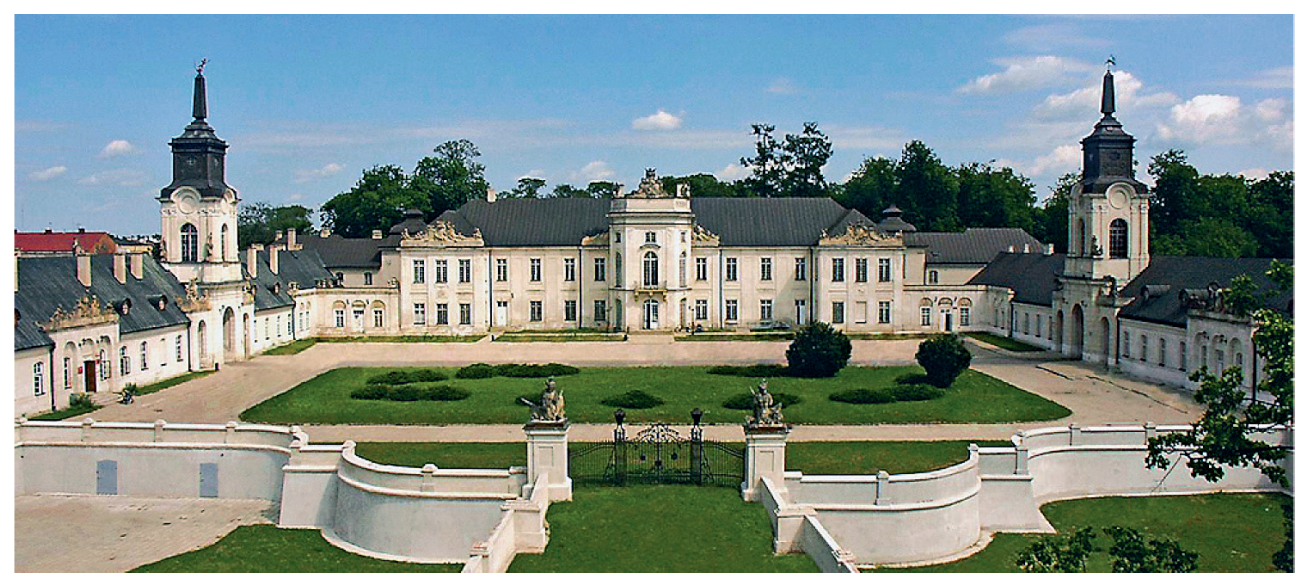

Fig. 12. Potocki Palace in Radzyń Podlaski-2017. Source: palac-potockich.pl [accessed on: 18.09.2017]

Organising an interesting and socially required and accepted function in its interior will be a contribution to the occurrence of a synergetic effect, i.e. an added value. It will be

\footnotetext{
4 A multi-branch project team for revitalization of the palace, headed by the main designer: Architectural team: Mieczysław Brzozowski, architect Katarzyna Święcicka-Brzozowska, architect, Tomasz Nicer, MSc, engineer, Tomasz Banaszek MSc, engineer (constructors), assistants: Magdalena Olszak, Łukasz Broniarek, electrician team: Arkadiusz Karwat, MSc, engineer; Remigiusz Karwat, MSc, sanitary team: Daniel Zarzycki, MSc, engineer; Agnieszka Gajewska, MSc, engineer; Marcin Kryczka, MSc, engineer in cooperation with Michał Kapczyński, Ph.D. (ASP in Warsaw).
} 
a result of the combination of the function integrating the inhabitants and the tourists and the value of the building as such - an urban nod. The influence and impact of the revitalised palace will be much bigger than it would be in the case of introduction of another function or situating the Centre of the Eastern Poland Culture in another facility 5 .

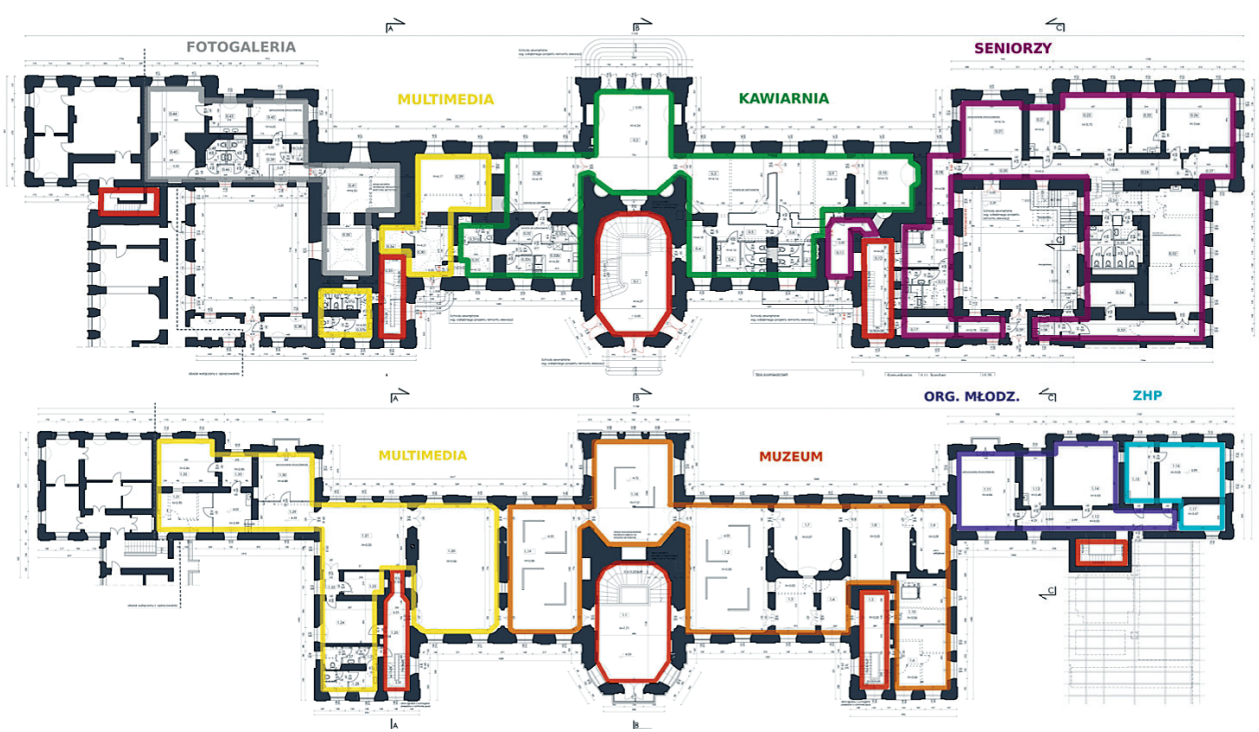

Fig. 13, 14. Approved functional program of the main part of the Potocki Palace- ground and first floor

In parallel to revitalising of Potocki Palace, also implemented is the "Program Rewitalizacji Miasta Radzyń Podlaski” [Radzyń Podlaski Revitalisation Programme] - Enlivening and Integration the Civic Society.

Revitalisation of Radzyń Podlaski matches the Lublin region revitalisation plan - currently approved are over 80 communal revitalisation programmes of the Lublin Voivodeship. Covered by the programme are such cities as Krasnystaw, Kock, Puławy, Ryki, Tomaszów Lubelski and Lublin as well as small towns including Wierzbica, Jastków, Jabłonna, Ułęż and many others. The programmes are financed within the framework of the Regional Programme for Lublin Voivodeship with co-financing from the EU.

In March, 2017, the "Miejski Program Rewitalizacji Miasta Radzyń Podlaski na lata 2016-2023” [Municipal Radzyń Podlaski Revitalisation Programme for the years 20162023] was prepared. It encompasses both social (such as education, health protection, unemployment) as well as economic (industry, tourism, technical infrastructure) and spatial issues. Other documents discuss financial framework, financing sources and models of the venture and project financing, the mechanisms of integration of the revitalising activities, and their complementary nature including social participation.

\footnotetext{
All the projects were consulted with the Voivodeship Monument Conserver and received its positive opinion. Following the opinion and questionnaire work, a conservation agenda was prepared concerning the following rooms: ground floor - entrance hall with the staircase, first floor - the parlor, library, and the chapel. A priority goal was to preserve the facility in the best possible condition, and what follows - limiting to a minimum the intervention linked with the adaptation works. An expert opinion was prepared and the decision of the Chief Commander of the Voivodeship Fire Brigade was obtained.
} 
The main goal of the programme is the increased level of live of its inhabitants and improved attractiveness of the revitalisation are by comprehensive social, spatial and economic revival. Additionally, three strategic goals were identified: supporting the social and professional activity of the local community and reinforcing the level of social integration in the area of revitalisation, creating conditions for economic development and improving the functionality and aesthetics of the public space in the areas subject to the programme.

From among the projects described in the Programme, three items from List A are worth quoting (A list of primary revitalisation projects):

No. 1 Revaluation of the ORANGERY and the Surrounding Site Management - a Park and Palace Complex in Radzyń Podlaski.

No. 2 Revaluation of the Historical Part in the Park and Palace Complex in Ra dzyn Podlaski

No. 3 Revaluation of the Public Space - RYNEK [market place] - in Radzyń Podlaski ${ }^{6}$

The revaluation of the Potocki Palace was also included on List A under item 4. It fulfils the postulates proposed in the Programme: it improves the attractiveness of a particular area, reinforces social integration, improves aesthetics and functionality of the public space and further on - also supports social and professional activity (work and entertainment using the new function). It is a promising beginning of changes which should take place in Radzyń.

\section{Potential model}

As regards the question of restoration of the strategic inheritance of Radzyń, the author believes it should follow the path determined by Zamość. This centre based its brand name on historic background by emphasising the monumental potential of the site.

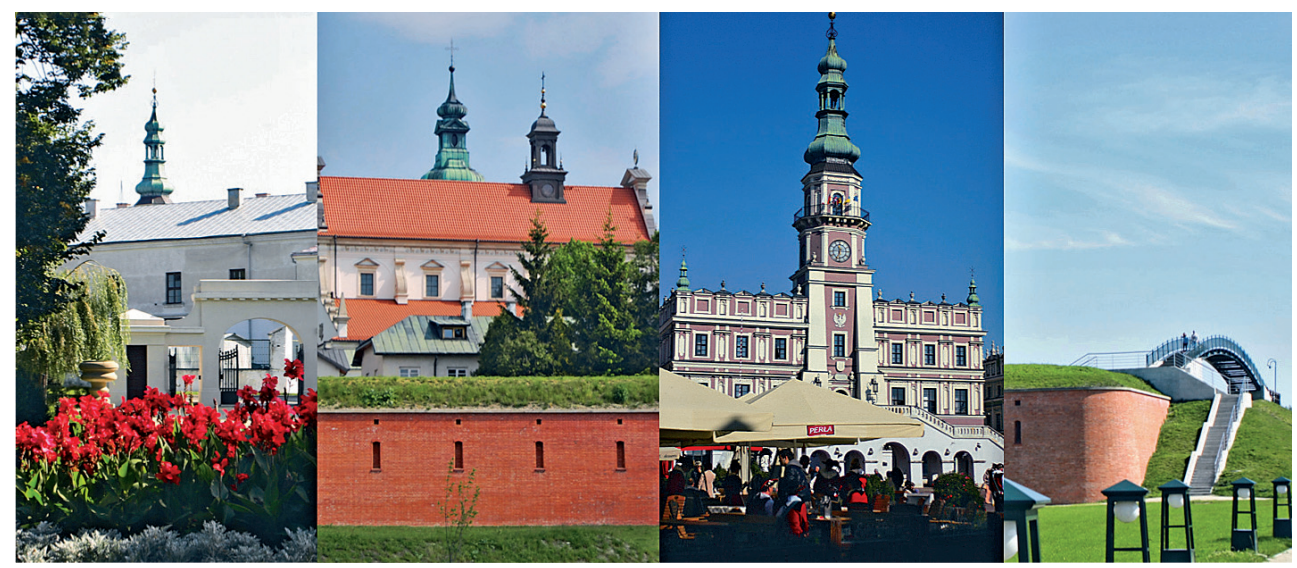

Fig. 15, 16, 17, 18. Zamość - revitalisation of the Old Town including fortifications. Author's photos

A number of activities were undertaken in Zamość aimed at increasing the attractiveness of the town for both its inhabitants as well as tourists. The process of revitalisation of the old town complex (including revaluation of the houses situated next to the main market),

\footnotetext{
6 „Miejski Program Rewitalizacji Miasta Radzyń Podlaski na lata 2016-2023” [Radzyń Podlaski Revitalisation Programme for the years 2016-2023], pp. 195-203.
} 
another stage was renovation and partial reconstruction of the city fortification and alignment of the green areas surrounding the Old Town. To this end, special subsidies were obtained among other things from EU funds.

In 1992, Zamość became a UNESCO and registered on the UNESCO World Heritage List, which converted into interest in the town also outside the territory of Poland and increased tourist traffic. Radzyń too has great chances of becoming an equally distinguished site - efforts have been undertaken to acknowledge Potocki Palace as a Historical Monument. This status is granted to immovable monuments of exceptional historic, scientific and artistic value reinforced in the general awareness and of considerable importance for the cultural heritage of Poland. The Monument of History is not only an ennoblement but it also entails increased financing. Zamość was granted the status on the $16^{\text {th }}$ of September, 1994.

Following the example of the Zamość model, the milestones in the development of Radzyń based on the heritage may be as follows:

- revitalisation

- promotion of tourism (attracting tourists with monuments and attractions - culture and recreation facilities, cycling culture paths, etc. hotel and catering infrastructure)

- obtaining funding for the consecutive revitalisation stages (among other things from the European funds) - other parts of the palace and park complex:
A. Palace wings (continuation of Project no. 4 from List A "Programme...")
B. Park and orangery design (projects no. 1 and 2)
C. Partner towns
D. Programme promoting the Palace with an emphasis on the architecture which is part of the park complex (continuation of Project no. 4 from List A "Programme....)

\section{Summary}

The valuable architecture situated in a key node may result in a synergy effect, i.e. an added value $(2+2=5)$. Its influence and effect on the surrounding neighbourhood may be incomparably higher than in the case of situation of an analogous facility in location. The anticipated result is revitalisation of the neighbourhood (district, embankment, housing estate) activation and integration of the inhabitants, improved space, and coalescence of the urban space.

A further, broadly planned and requiring consecutive actions - initiated by the said facility - outcome may be the change of the city's image and resto ration of the cohesion of its space. The synergetic effect occurred among other things in the case of the Opera House in Oslo, Elbphilarmonie in Hamburg and the Eye Film Institute Netherlands, where the combination of an interesting and necessary functions and the 'nod' location resulted in the revival of the entire neighbourhood.

An important aspect is restoration of the value of the historical sites and nodes which lost their importance as a result of disadvantageous historic events and spatial transformations. This situation took place in the case of Potocki Palace in Radzyń Podlaski. Thanks to the introduction of an attractive function into the Palace, i.e. Centrum Kultury Polski Wschodniej, the facility will recover its integrating role - it will resume the position of a showcase of Radzyń, a magnet attracting tourists. It will also be interesting for the inhabitants - both as a potential place of work as well as recreation. It may become a bridgehead of broader changes - revitalisation and changes in the image of the entire city. 


\section{References}

[1] Ashworth G., Planowanie dziedzictwa. Międzynarodowe Centrum Kultury, Kraków 2015.

[2] Böhm A., O budowie i synergii wnętrz urbanistycznych. Monografia nr 6, Wydawnictwo Politechniki Krakowskiej, Kraków 1981.

[3] Dokumentacja zgłoszenia Zespołu Pałacowo-Parkowego Potockich w Radzyniu Podlaskim do objęcia wyższą formą ochrony poprzez uznanie go za Pomnik Historii, Urząd Miasta, Radzyń Podlaski 2016.

[4] Dziubecki T., Rezydencja w Radzyniu Podlaskim jako miejsce ksztattujące wyobraźnię architektoniczna Stanistawa Kostki Potockiego. Przyczynek do źródet architektury klasycyzmu w Polsce. Architecturae et Artibus 1 (2013) 39-49.

[5] Fiuk P., Symbole nowoczesności w strukturze zabytkowych miast Europy. Czasopismo Techniczne 6-A(15) (2008) 294-298.

[6] Gombin K., Pałac Eustachego Potockiego w Radzyniu Podlaskim jako wyznacznik społecznej pozycji magnata, Radzyński Rocznik Humanistyczny 6 (2008) 55-66.

[7] Karpowicz M., Sztuka polska XVIII wieku. Wydawnictwa Artystyczne i Filmowe, Warszawa 1985.

[8] Karta ewidencyjna zabytku nieruchomego wpisanego do Rejestru Zabytków (,,Biała Karta”) - PaŁac w Radzyniu Podlaskim. Wojewódzki Oddział Służby Ochrony Zabytków w Lublinie, Delegatura w Białej Podlaskiej, 1981.

[9] Kubicki P., Wynajdywanie miejskości. Polska kwestia miejska z perspektywy dtugiego trwania, NOMOS, Wydział Studiów Międzynarodowych i Politycznych Uniwersytetu Jagiellońskiego, Kraków 2016.

[10] Miasta polskie w tysiacleciu, tom pierwszy. Praca zbiorowa, Zakład Narodowy im. Ossolińskich, Wrocław - Warszawa - Kraków 1965.

[11] Pietrzela T., Radzyń Podlaski i okolice w pradziejach i średniowieczu, Radzyński Rocznik Humanistyczny 6 (2008) 11-27.

[12] Radzyń Podlaski. Miasto i rezydencja. red. G. Michalska i D. Leszczyńska, Radzyń Podlaski 2011.

[13] Rykwert J., Pokusa miejsca. Przeszłość i przyszłość miast. Międzynarodowe Centrum Kultury, Kraków 2013.

[14] Szmygin B. (red.), Adaptacja obiektów zabytkowych do współczesnych funkcji użytkowych. Lubelskie Towarzystwo Naukowe Międzynarodowa Rada Ochrony Zabytków ICOMOS Politechnika Lubelska Warszawa - Lublin 2009.

[15] Wrana J., Wspótczesna forma architektoniczna a kontekst miejsca, Modern architectural form and place context. Czasopismo Techniczne 1-A (2009) 589-593.

[16] Wrana J., Architektura - zrozumialy komunikat przestrzenny, Architecture - a clear spatial message. Czasopismo Techniczne 1-A (2009) 413-416.

[17] Wrana J., Fitta-Spelina A., Pałac Potockich w Radzyniu Podlaskim - zagadnienie rewitalizacji obiektu. Człowiek - Ekologia - Architektura, Poznań 2017.

[18] Wrana J., Jarocka-Mikrut A., Nowa szansa dla obiektów zabytkowych poprzez przeprowadzenie rewitalizacji i wprowadzenie funkcji użytkowych, Budownictwo i Architektura 12(3) (2013) 271-278.

[19] Zmieniając miasto - wokót teorii i praktyki rewitalizacji. Praca zbiorowa pod red. M. Kowalewskiego, FTA, Poznań 2008.

[20] Zuziak Z.K., Nowe struktury w przestrzeni metropolitalnej. Pytania i problemy planistyczne. Czasopismo Techniczne 5-A (2008) 4-18.

[21] Zuziak Z., Strategic metropolitan projects - examples from Hamburg, Potsdam and Berlin. Czasopismo Techniczne 1-A (2013) 195-222.

[22] Zuziak Z.K., Zmiany strukturalne w miastach polskich na poczatku XXI. Między sztuka budowania miast a polityka przestrzenna. Halicka A.(red), Budownictwo na obszarach zurbanizowanych, Nauka, praktyka, perspektywy, Lublin. Politechnika Lubelska; s. 165-176, 2014.

[23] Zuziak Z.K., The Notion of Order and the Spatial Logic of a New Polis: Three Approaches to the Problem of Rationality in the Contemporary Philosophy of Urbanism, 11 CTV, Back to the sense of the City, Barcelona, Kraków, 2016.

[24] Zuziak Z.K., O synergii planu w urbanistyce. Budownictwo i Architektura 16(1) (2017) 183-198. 